\title{
Effect of Casting Machine on Nickel-Chromium Alloy Castings for Fixed Prosthesis
}

Part 1. Change in Tensile Strength

Kiyoshi TAJIMA, Hiroshi KAKIGAWA, Yoshio KOZONO and Ichiro HAYASHI

Department of Materials Science, Kyushu Dental College, 2-6-1 Manazuru, Kokurakita, Kitakyushu 803, Japan

Received on March 31, 1986

The effect of the type of casting machine (Argoncaster, Acetron, Sure, Castmatic, Diner and Thermotrol) on the tensile strength of nine commercial $\mathrm{Ni}-\mathrm{Cr}$ alloys for crown and bridge and for ceramo-metal restoration, and of two precious alloys for comparison was examined.

The tensile strength of both types of $\mathrm{Ni}-\mathrm{Cr}$ alloys was greatly affected by the casting machine used, but not that of the precious alloys. There were significant differences in the effect of casting machine between the $\mathrm{Ni}$-Cr alloys for crown and bridge and those for ceramo-metal. Argoncaster was relatively compatible with the Ni-Cr alloys for crown and bridge, while Diner and Castmatic showed better compatibility with the $\mathrm{Ni}-\mathrm{Cr}$ alloys for ceramo-metal restoration.

Key words : Dental casting alloy, Dental casting machine, Tensile strength

\section{INTRODUCTION}

Many dental casting $\mathrm{Ni}-\mathrm{Cr}$ alloys for fixed prosthesis are currently available. These $\mathrm{Ni}-\mathrm{Cr}$ alloys are classfied into two types, namely those for crown and bridge, and those for ceramo-metal restoration ${ }^{1-4}$.

For melting and casting the $\mathrm{Ni}-\mathrm{Cr}$ alloys having high fusion temperatures, several high-energy heating sources such as arc, high frequency induction, and flame with oxygencontaining gas mixture are usually applied in combination with casting pressures such as centrifugal force, vacuum-pressure and suction-pressure. These various types of casting machines are commercially available $e^{5-7}$.

Several reports ${ }^{8-11}$ have already been made on the representative melting methods for early nonprecious alloys intended for removable prosthesis. These evaluations, however, are not always applicable to current $\mathrm{Ni}-\mathrm{Cr}$ alloys for fixed prosthesis. Although the surface roughness, castability, mechanical properties of a few current alloys have also been examined using several casting machines ${ }^{12-17)}$, which casting machine is preferable to produce consistently satisfactory $\mathrm{Ni}-\mathrm{Cr}$ alloy casting has not been determined.

Several types of casting machines were compared in this study by examining the tensile strength of the casting for five commercially available $\mathrm{Ni}-\mathrm{Cr}$ alloys for crown and bridge and four for ceramo-metal restoration.

\section{MATERIALS AND METHODS}

Table 1 shows the alloys used in this study along with their alloy composition as 
Table 1 Alloys used

\begin{tabular}{|c|c|c|c|c|c|c|c|c|}
\hline \multirow{2}{*}{ Alloy name } & \multirow{2}{*}{ Code } & \multicolumn{6}{|c|}{ Alloy composition published } & \multirow{2}{*}{ Manufacturer } \\
\hline & & $\mathrm{Ni}$ & $\mathrm{Cr}$ & $\mathrm{Si}$ & Other & & & \\
\hline Super Soft & SPS & 93 & 6 & & 1 & & & Towa Giken Co., Osaka \\
\hline Summalloy $\mathrm{Ni} \mathrm{S}$. & SMS & 84 & 9 & & 7 & & & Shofu Inc., Kyoto \\
\hline Suncolium U.S. & SCU & 90 & 10 & & & & & Sankin Industry Co., Osaka \\
\hline Taicrown & TCR & 82 & 13 & & 5 & & & Taisei Industry Co., Osaka \\
\hline \multirow[t]{2}{*}{ Nirostar } & NST & 72 & 19 & 6 & 3 & & & Nippon Shiken Dental Co., Tokyo \\
\hline & & $\mathrm{Ni}$ & $\mathrm{Cr}$ & Mo & $\mathrm{Fe}$ & $\mathrm{Al}$ & Others & \\
\hline SB $\cdot$ Bondloy I & SBB & 56.4 & 17.4 & 12.4 & 9.9 & \multirow{4}{*}{5} & 3.9 & Towa Giken Co., Osaka \\
\hline Nichrome Bond & NCB & 59 & 20 & 15 & & & 6 & Sankin Industy Co., Osaka \\
\hline Negium & NGM & 53 & 30 & 6.5 & & & 5.5 & Towa Giken Co., Osaka \\
\hline \multirow[t]{2}{*}{ Uni Metal* } & UNM & 77 & 14.9 & & & & 8.1 & Shofu Inc., Kyoto \\
\hline & & $\mathrm{Au}$ & $\mathrm{Ag}$ & $\mathrm{Pd}$ & $\mathrm{Cu}$ & \multicolumn{2}{|c|}{ Others } & \\
\hline \multirow{2}{*}{$\begin{array}{l}\text { Casting Gold } \\
\text { Type III M.C. } \\
\text { Castwell M.C. }\end{array}$} & CGIII & 75 & 7 & 3 & 15 & \multirow{2}{*}{\multicolumn{2}{|c|}{8}} & \multirow{2}{*}{$\begin{array}{l}\text { G C Dental Industry Corp., Tokyo } \\
\text { G-C Dental Industry Corp., Tokyo }\end{array}$} \\
\hline & CWL & 12 & 45 & 20 & 15 & & & \\
\hline
\end{tabular}

* Beryllium is known to be present, but the amount is uncertain.

Table 2 Casting machines used

\begin{tabular}{|c|c|c|c|c|}
\hline Casting machine & Heating source & Atomosphere & Pressure type & Manufacturer \\
\hline Argoncaster-DX & $\begin{array}{l}\text { High frequency } \\
\text { induction }\end{array}$ & $\begin{array}{l}\text { Argon gas } \\
\text { in chamber }\end{array}$ & Vacuum-pressure & Shofu Inc., Kyoto \\
\hline Acetron SA-200 & $\begin{array}{l}\text { High frequency } \\
\text { induction }\end{array}$ & Air & Centrifugal force & $\begin{array}{l}\text { Sankin Industry Co., } \\
\text { Osaka }\end{array}$ \\
\hline Sure CV-51 & $\begin{array}{l}\text { A gas mixture } \\
\text { flame* }\end{array}$ & Air & Centrifugal force & $\begin{array}{l}\text { Yamano Dental } \\
\text { Supply Co., Tokyo }\end{array}$ \\
\hline Castmatic CM-230 & Arc & $\begin{array}{l}\text { Argon gas } \\
\text { in chamber }\end{array}$ & Suction-pressure & Iwatani \& Co., Osaka \\
\hline Diner OAC-200 & Arc & $\begin{array}{l}\text { Argon gas } \\
\text { blow in air }\end{array}$ & Centrifugal force & Ohara Co., Osaka \\
\hline Thermotrol 2500 & $\begin{array}{l}\text { Electrical } \\
\quad \text { resistance }\end{array}$ & Air & Centrifugal force & $\begin{array}{l}\text { J.F. Jelenko \& Co., } \\
\text { N.Y., U.S.A. }\end{array}$ \\
\hline
\end{tabular}

Each casting was performed with no flux.

* Propane gas-oxygen flame was used for $\mathrm{Ni}-\mathrm{Cr}$ alloys, and town gas-air flame for precious alloys.

\# Graphite crucible was used.

Table 3 Investments used

\begin{tabular}{llll}
\hline Alloy & Investment & Investment type & \multicolumn{1}{c}{ Manufacturer } \\
\hline Ni-Cr & Ceravest & Phosphate-bonded & Taisei Dental Co., Osaka \\
CGIII & Harbar Vest & Cristbalite & Nitto Gypsum Co., Nagoya \\
CWL & Pallavest & Quartz & G-C Dental Industry Corp., Tokyo \\
\hline
\end{tabular}

provided by the manufacturer. The top five $\mathrm{Ni}-\mathrm{Cr}$ alloys are for crown and bridge use, and the middle four are for ceramo-metal restoration. The bottom two are a conventional type III casting gold alloy and a casting Ag-Pd-Au alloy chosen as the control.

Six available casting machines were used (Table 2). Five casting machines, Argoncas- 
ter, Acetron, Sure, Castmatic and Diner, were adopted for the Ni-Cr alloys, and three casting machines, Argoncaster, Sure and Thermotrol, were used for the precious alloys. When Sure was used, a propane gas-oxygen flame* was employed to melt the $\mathrm{Ni}$ - $\mathrm{Cr}$ alloys and a town gas-air flame ${ }^{\#}$ for the precious alloys.

Original rod patterns $(2.1 \phi \times 45 \mathrm{~mm})$ were longitudinally invested in the ordinal casting ring, using the investments 'shown in Table 3 . The mold temperature was $800^{\circ} \mathrm{C}$ for the $\mathrm{Ni}-\mathrm{Cr}$ alloys and $700^{\circ} \mathrm{C}$ for the precious alloys.

In the case of Castmatic, the alloy was automatically cast through its systematized process $^{14)}$, and in Thermotrol the casting temperature was preset at the temperature approximately $100^{\circ} \mathrm{C}$ higher than the melting temperature for each alloy. The most suitable instant for the alloy to be cast was determined visually from the appearance of the molten alloy, except for Castmatic and Thermotrol. All the casting procedures were performed by a specific operator to avoid any possible individual deviations among the operators.

Six casting specimens of each $\mathrm{Ni}-\mathrm{Cr}$ alloy and three specimens of each precious alloy were made with each casting machine. All castings were checked for cast tearing by the naked eye, and only the apparently undefective castings were subjected to tensile testing with a universal test machine ${ }^{\$}$ at a crosshead speed of $5 \mathrm{~mm} / \mathrm{min}$ to determine the ultimate tensile strength.

\section{RESULTS}

Figure 1 shows the average tensile strength of the castings for $\mathrm{Ni}-\mathrm{Cr}$ alloys for crown and bridge, Fig. 2 that for the Ni-Cr alloys for ceramo-metal restoration and Fig. 3 that for the precious alloys when each casting machine was employed. Cast-torn specimens were visually noticed in some of the castings made of $\mathrm{Ni}$-Cr alloys for crown and bridge, and the numerals in Fig. 1 denote their numbers. The tensile strength of both types of $\mathrm{Ni}-\mathrm{Cr}$ alloys were greatly affected by the type of casting machine used, as compared with that of the precious alloys. Considerable differences in the effect on the tensile strength were also observed between the crown and bridge type and the ceramo-metal type, and the changes were more liable to occur in the former than in the latter.

The results were subjected to a two-way analysis of variance to test the statistical significance among the alloy brands and the casting machines in each of the three types of alloys. The cast-torn $\mathrm{Ni}$-Cr casting specimens, which had been already broken at devesting before the tensile test, were also subjected to the analysis, in which their values of the tensile strength were estimated to be $0 \mathrm{kgf} / \mathrm{mm}^{2}$. There were significant differences both among the alloy brands $(\mathrm{p}<0.01)$ and among the casting machines $(\mathrm{p}<0.01)$ in each of the two $\mathrm{Ni}$-Cr alloy types. Interactions between the above two factors were also found $(p<0.01)$. In the precious alloys, on the other hand, there was a significant difference only between the two alloys $(\mathrm{p}<$ 0.01 ), and no significant difference among the casting machines ( $p>0.05)$.

Then, the t-test was performed to detemine the differences among the casting machines

\footnotetext{
* Torch New OP Type, Nippon Iryoki, Tokyo

\# Torch DN-OP Type, Nippon Iryoki, Tokyo

$\$$ TCM 5000-C, Shinkoh, Tokyo
} 


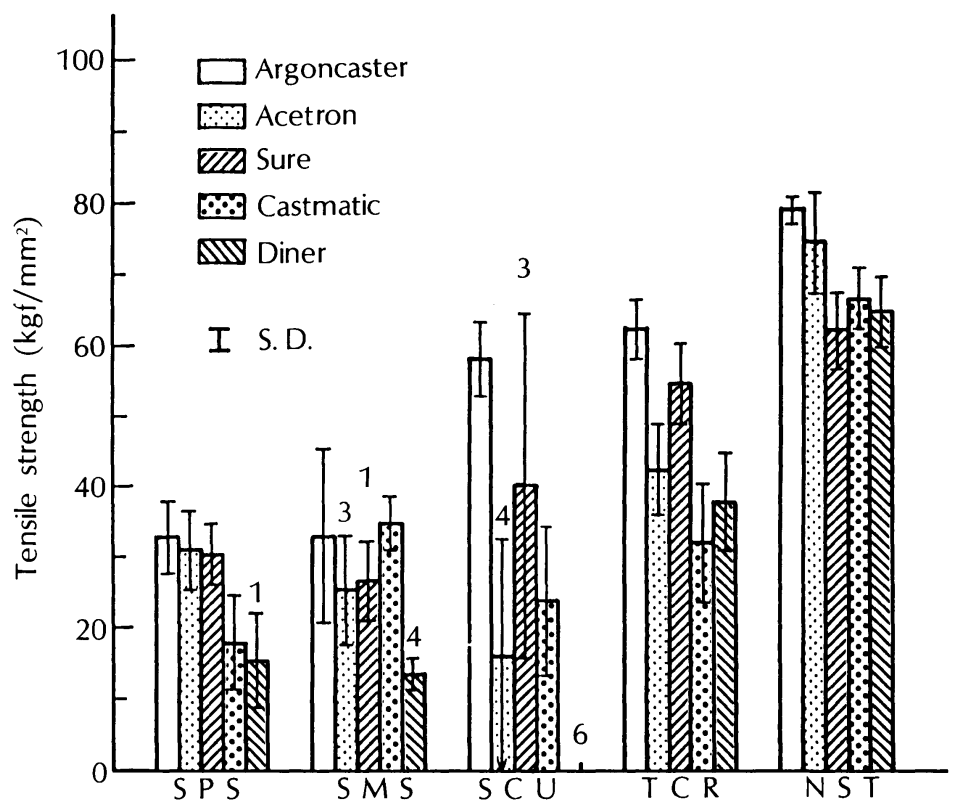

Fig. 1 Effect of casting machine on tensile strength of the $\mathrm{Ni}-\mathrm{Cr}$ alloys for crown and bridge.

Numerals in figure indicate the number of the castings broken during casting.

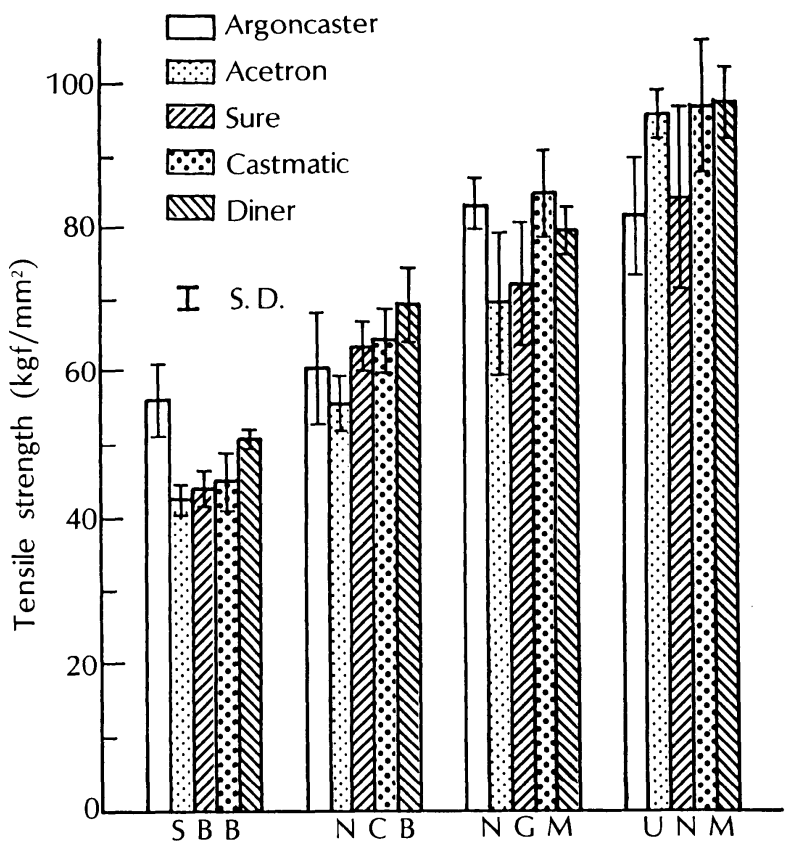

Fig. 2 Effect of casting machine on tensile strength of the Ni-Cr alloys for ceramometal restoration. 


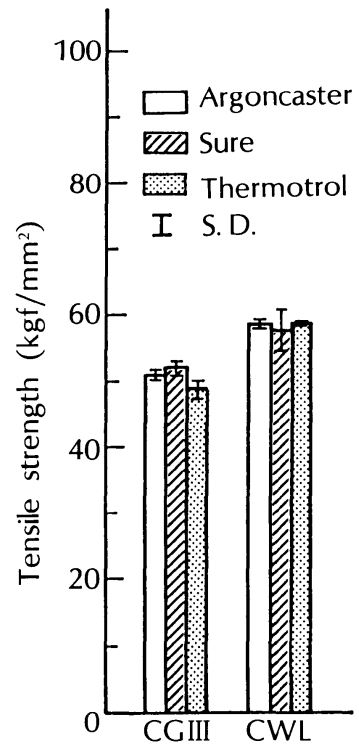

Fig. 3 Effect of casting machine on tensile strength of the precious alloys.

Table 4 Significance of the differences in the tensile strength among casting machines for each of the two $\mathrm{Ni}-\mathrm{Cr}$ alloy types

a ) $\mathrm{Ni}-\mathrm{Cr}$ alloys for crown and bridge

\begin{tabular}{ll|ccccc}
\hline A:Induc/Ar & $(53.0) \$$ & - & & & & \\
B:Flame/Air $(37.8)$ & $* *$ & - & $\mathrm{CI}= \pm 3.3$ \\
C:Arc/Ar & $(35.1)$ & $* *$ & $\mathrm{n}$ & - & & \\
D:Induc/Ar & $(33.2)$ & $* *$ & $*$ & $\mathrm{n}$ & - & \\
E:Arc/Ar (b) & $(24.0)$ & $* *$ & $* *$ & $* *$ & $* *$ & - \\
\hline & A & B & C & D & E
\end{tabular}

b) $\mathrm{Ni}$-Cr alloys for ceramo-metal restoration

\begin{tabular}{l|cccccc}
\hline $\mathrm{A}: \operatorname{Arc} / \mathrm{Ar}(\mathrm{b})$ & $(74.2)$ & - & & & & \\
$\mathrm{B}: \operatorname{Arc} / \mathrm{Ar}$ & $(72.8)$ & $\mathrm{n}$ & - & & $\mathrm{CI}= \pm 2.5$ \\
$\mathrm{C}:$ Induc/Ar & $(70.4)$ & $*$ & $\mathrm{n}$ & - & & \\
$\mathrm{D}:$ Flame/Air & $(66.1)$ & $* *$ & $* *$ & $*$ & - & \\
$\mathrm{E}:$ Induc/Air & $(65.9)$ & $* *$ & $* *$ & $*$ & $\mathrm{n}$ & - \\
\hline & $\mathrm{A}$ & $\mathrm{B}$ & $\mathrm{C}$ & $\mathrm{D}$ & $\mathrm{E}$
\end{tabular}

$\$$ : mean tensile strength of all of the castings made by each casting machine, $\mathrm{kgf} / \mathrm{mm}^{2}$

$*$ : significant at $\alpha=0.01$

**: significant at $\alpha=0.05$

$\mathrm{n}:$ not significant at $\alpha=0.05$

CI $: 95 \%$ confidence interval

for each of the two $\mathrm{Ni}-\mathrm{Cr}$ alloy types (Table 4). In the crown and bridge type of alloys, the castings made by Argoncaster had the greatest strength with a statistical significance $(\mathrm{p}<$ $0.01)$ and those made by Diner had the smallest $(p<0.01)$. In the case of the ceramo-metal type, the castings made by Diner or Castmatic had significantly greater tensile strength than those made by Acetron or Sure $(p<0.01)$.

\section{DISCUSSION}

Dental casting Ni-Cr alloys have been introduced as alternatives to precious alloys. As 
generally known, however, their properties are considerably different from those of the gold based alloys ${ }^{18-22)}$. In addition, $\mathrm{Ni}$ - $\mathrm{Cr}$ alloys are much more sensitive to the casting procedure than precious alloys ${ }^{23,24}$. This study also revealed that the tensile strength of these alloys varied extremely with the casting machine used when compared with that of the precious alloys.

The commercially available $\mathrm{Ni}$-Cr alloys are different in mechanical properties because of their large variations in composition ${ }^{18,21,25)}$. The user must choose an alloy on the basis of the clinical need by consulting the manufacturers' informations. The properties of the casting alloys, however, may occasionally vary with the process of fabricating the restoration. This study was focused on the effects of the type of casting machine used on the tensile strength of two types of the $\mathrm{Ni}-\mathrm{Cr}$ alloys for fixed prosthesis.

There was no comparison between Argoncaster and Diner concerning their compatibility with the Ni-Cr alloys for crown and bridge. Argoncaster showed the best compatibility with all of the alloys, while Diner dramatically lowered the tensile strength to the level below the value provided by the manufacturer. As previously reported ${ }^{23)}$, the use of Diner caused marked gas uptake in some Ni-Cr alloys (Super Soft and Summalloy Ni Soft). Such a gas uptake may partly account for the deterioration of the castings when Diner is employed. The melting in an inert gas atmosphere is generally considered desirable for alloys being easily oxidized such as the nonprecious dental alloys ${ }^{7,26)}$. In both Argoncaster and Diner the alloys are melted in an argon gas atmosphere. However, the use of argon gas seems not always to be as effective in every casting machine as generally expected, the reason of which is uncertain. The two casting machines use different argon gas supplying methods as well as different heating sources (Table 2), and further studies will be necessary to clarify the relationships between them.

As mentioned above, Argoncaster was the most suitable casting machine for any of the $\mathrm{Ni}-\mathrm{Cr}$ alloys for crown and bridge tested. In the case of the alloys for ceramo-metal restoration, on the other hand, the compatibility of the casting machine differed with the alloy brands used (Fig. 2). The statistical analyses showed the general tendency that melting in the air (Sure and Acetron) resulted in the decrease of tensile strength and melting in an argon gas atmosphere (Diner, Castmatic and Arogoncaster) resulted in an increase as expected. It must be noted that Argoncaster could not always give the best results with the ceramo-metal type alloys as it could with the crown and bridge type alloys. Especially with the alloy Uni Metal (UNM), the tensile strength was much lower than the manufacturer's announcement when it was cast by Argoncaster (Fig. 2), indicating that Argoncaster was incompatible with this alloy. Thus, it is more difficult to predict the adequate alloy-casting machine combination in the Ni-Cr alloys for ceramo-metal than those for crown and bridge.

The significant differences seen between the two Ni-Cr alloy types and even among the alloy brands must be attributed to their different alloy composition. The contents of the primary elements, nickel and chromium, are substantially different between the two types; the crown and bridge alloys include higher amount of nickel and lower chromium than the ceramo-metal alloys. The content of these elements also differs with the alloy brand in each type. Such differences in composition, however, were not reflected on the variations of the tensile strength. The sensitiveness to the casting machine appears to result from the 
additional elements such as deoxidizer. Further in the case of the ceramo-metal type, the presence of the inherent additives for improving the bond with porcelain, thermal expansion and other properties of the alloys ${ }^{4,19,20}$ might make the alloy-casting machine combination more selective.

The casting procedure includes many manipulative variables in the stage of investing, melting and casting. From the results in this study it was found that the selection of the casting machine was one of the greatest factors affecting the tensile strength of the $\mathrm{Ni}-\mathrm{Cr}$ alloy castings. There was no single almighty casting machine for all the $\mathrm{Ni}-\mathrm{Cr}$ alloys used so far as the tensile strength was concerned. Therefore, it is inevitable, for the present, to select the optimum casting machine for each alloy. Improvements of the alloys and/or the casting machines are awaited to minimize the deterioration of the alloy by the casting procedure.

\section{CONCLUSIONS}

The effect of the casting machine on the tensile strength of several commercially available $\mathrm{Ni}-\mathrm{Cr}$ alloys for crown and bridge and for ceramo-metal restoration, and of two precious alloys as the control was examined.

The following results were obtained.

(1) The tensile strength of both types of $\mathrm{Ni}$-Cr alloys were greatly affected by the casting machine used, as compared with that of the precious alloys.

(2) The effect on the $\mathrm{Ni}-\mathrm{Cr}$ alloys for crown and bridge was also considerably different from that on the alloys for ceramo-metal restoration.

(3) Larger variations were liable to appear with different casting machines in the crown and bridge type alloys than in the ceramo-metal type alloys.

(4) Argoncaster was generally compatible with the alloys for crown and bridge, while Diner was incompatible.

(5) Diner or Castmatic was relatively compatible with the $\mathrm{Ni}-\mathrm{Cr}$ alloys for ceramo-metal restoration, while Sure or Acetron was relatively incompatible with them.

\section{REFERENCES}

1) Nakamura, K., Goto, S., Yamatoya, F., Fukuda, T., Onozato, Y., Hasegawa, T. and Nakai, A. : Properties of casting nickel-chromium alloys for crown and bridge, Shigaku 73 (4) : 930-945, 1985. (in Japanese)

2) Noguchi, H.: Porcelain veneering alloy today, Quintessence extra issure : 23-30, 1983. (in Japanese)

3) Shinya, A. : Study of the alloy used in porcelain fused to metal restorations, Quintessence 2 (6) : 63-77, 1983. (in Japanese)

4) Bertolotti, R. L. : Selection of alloys for today's crown and fixed partial denture restorations, $J A m$ Dent Assoc 108 (6) : 959-966, 1984.

5) Nomura, J., Okada, H. and Nakaya, K. : Theoretical views of fabricating cast plates and practical laboratory procedures (19), J Dent Technol 10 (6) : 519-532, 1982. (in Japanese)

6) Nomura, J., Okada, H. and Nakaya, K. : Theoretical views of fabricating cast plates and practical laboratory procedures (20), J Dent Technol 11 (1) : 87-99, 1983. (in Japanese)

7) Yamaga, R., Tsutsumi, S. and Ida, K. : Non-oxygen casting of high fusing-temperature alloys and alloys for fused porcelain, J Osaka Univ Dent Sch 15: 47-62, 1975. 
8) Harcourt, H. J. and Cotterill, W. F.: Induction melting of cobalt-chromium alloys - a comparison with flame melting, Brit Dent J 118 (8) : 323-329, 1965.

9) Strandman, E.: The influence of carbon content of the mechanical properties in a cast dental $\mathrm{Co}-\mathrm{Cr}$ alloy,Odont Revy 27 (4) : 273-286, 1976.

10) Lewis, A. J. : A radiographic evaluation of microporosity in a nickel base casting alloy, Aust Dent J 20 (4) : 221-226, 1975.

11) Nasu, T., Hikichi, H. and Noguchi, H.: On defect of cobalt-chromium-nickel alloy for dental castings, J Japan Soc Dent Appar Mat 19 (45) : 39-47, 1977. (in Japanese)

12) Phillips, R. W. : Skinner's science of dental materials, 8th ed., W. B. Saunders Co., 1982, pp. 555-560.

13) Hayashi, H.: Nickel-chromium alloy casting by using an argon-arc casting machine 1 . Surface roughness, J Stomatol Soc 44 (4), 293-302, 1977. (in Japanese)

14) Ida, K., Togaya, T., Takahashi, J., Yamaga, T., Yamada, T. and Nokubi, T.: The measurement of fusing time of alloys with various heat sources in dental casting, J Japan Res Soc Dent Mat Appl 35 (3) : 234-244, 1978. (in Japanese)

15) Ida, K., Tsutsumi, S., Togaya, T. and Takeuchi, M. : Structure and properties of new dental casting machine "CASTMATIC", Bull Stom Kyoto Univ 19 (Bound volume) : 33-44, 1979. (in Japanese)

16) Asgar, K. and Arfaei, A. H. : Castability of crown and bridge alloys, J Prosthet Dent 54 (1): 60-63, 1985.

17) Kito, M. Honda, Y., Kawamura, N., Iwai, K. and Hasegawa, J.: The casting rate of Ni-Cr casting alloys for crown and bridge - effect of casting method - , J J Dent Mat 3 (4) : 508-514, 1984. (in Japanese)

18) Moffa, J. P. : Physical and mechanical properties of gold and base metal alloys. In Valega, T. M. ed. : Alternatives to gold alloys in dentistry. DHEW Pub. No. (NIH) 77-1227, 1977, pp. 81-93.

19) Kelly, J. R. and Rose, T. C.: Nonprecious alloys for use in fixed prosthodontics : A literature review, J Prosthet Dent 49 (3) : 363-370, 1983.

20) Baran, G. R. : The metallurgy of Ni-Cr alloys for fixed prosthodontics, J Prosthet Dent 50 (5) : 639-650, 1983.

21) Hasegawa, J. : Properties of Ni-Cr alloys for castings, J J Dent Mat 3 (5) : 547-553, 1984. (in Japanese)

22) Inoue, M., Tabata, T., Haga, M. and Yokotsuka, S. : Clinical evaluation of nickel-chromium alloys for crown and bridge work, J Japan Prosth Dent 28 (7) : 25-41, 1984. (in Japanese)

23) Tajima, K., Kakigawa, H., Kozono, Y. and Hayashi, I. : Oxygen and nitrogen uptake in dental $\mathrm{Ni}-\mathrm{Cr}$ alloy castings by several melting methods, Dent Mater J 3 (2) : 262-271, 1984.

24) Reisbick, M. H. ed. : Dental materials in clinical dentistry, lst ed., John Wright - PSG Inc, 1982, pp. 198 -203 and 241-245.

25) Johnson, L. N.: The physical properties of some alternative alloys, Int Dent J 33 (1) : 41-48, 1983.

26) Ida, K. : Dental casting technique - for preventing casting defects -, Bull Stom Kyoto Univ 18 (Bound volume) : 1-15, 1978. 
ついて高い評価が得られ他の床用材料にはみられない特 長が示された。

以上，いくつかの基礎実験と臨床観察との結果を考え
合わせると，今後さらに改良すべきいくつかの点を残し ているとはいえ TRUTISSUは床用材料として有用な 材料であることが理解できた。

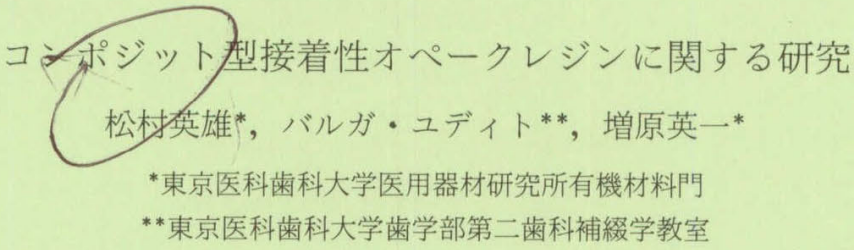

コンポジット型接着性オペークレジンの諸性質を検討 した。このレジンで同種合金どうしを接着した場合, $\mathrm{Sn}$ 電析処理をした Type IV金合金や金銀パラジウム合金, およびサンドブラスト処理したステンレス鋼などはすく れた接着耐久性を示した。一方このレジンで硬質レジ
ンと合金を接着する場合は，操作性に改善の余地が認め られた。その他，光重合型歯冠用硬質レジンの物性に対 し，熱と照射時間が影響を及ほしていることが明らかと なった。

\section{クラウン・ブリッジ用および陶材焼付用 $\mathrm{Ni}-\mathrm{Cr}$}

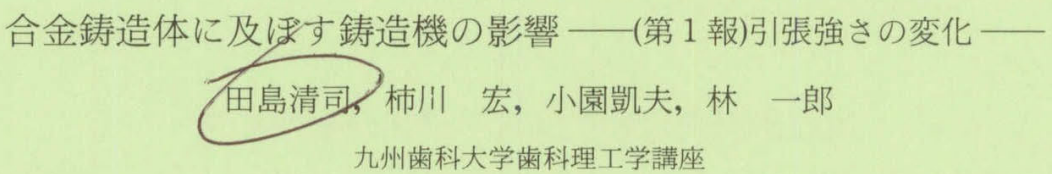

市販のクラウン・ブリッジ用および陶材焼付用 Ni-Cr 合金 9 種類を， 5 種類の歯科用鋳造機を用いて溶融・鋳 造し，鋳造機による鋳造体の引張強さの差異を調ぺた。 また貴金属系合金 2 種類を 3 種類の鋳造機により溶融・ 鋳造し, $\mathrm{Ni}$ - Cr 合金の場合と比較した。

$\mathrm{Ni}$-Cr 合金の引張強さには貴金属系合金の場合に比べ て，使用した鋳造機が大きく影響を与えていた。この影 響は $\mathrm{Ni}$-Cr 合金のタイプ別，さらに同じタイプでも合金 ごとに異なっており，特に，クラウン・ブリッジ用合金
では著しい引張強さの変化が認められた。本実験に用い た鋳造機の中で，クラウン・ブリッジ用 Ni-Cr 合金には アルゴンキャスター（アルゴンガス雲井気溶融十真空加 圧鋳造)が，一方陶材焼付用 Ni-Cr 合金にはダイナー(大 気中アルゴンガス吹付けアーク溶融十遠心鋳造）あるい はキャストマチック（アルゴンガス雾井気アーク溶融+ 吸引加圧鋳造）が，引張強さの高い鋳造体を与える傾向 にあった。

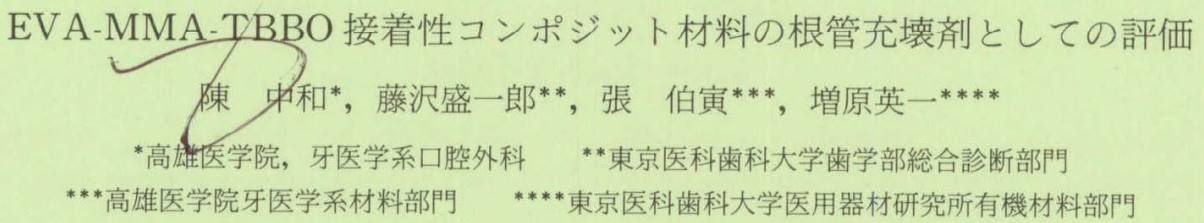

EVA-MMA, AH26, Super bond, 酸化要鉛ユージノー ルを用いて透過性テストを行ない, 根管封鎖性を評価し た。EVA-MMA, AH26, Super bond は酸化垔鉛ユージ ノールより封鎖性が良かった。EVAコンポジットは根
管壁適合に対し最も良好な性質を示した。EVA-MMA， KP-MMA，ハイドロキシアパタイト (HAP) をサルの 抜歯曧にインプラントする系と EVA-MMA，KP. MMA, PMMA をラットの皮下にインプラントする系 